\title{
Who do We think We are - the Finnishness in Finnish-American songs
}

\author{
JUHA NIEMELÄ, M.A. \\ Researcher \\ Institute of Migration \\ Turku, Finland
}

\section{Abstract}

From the last part of the 19th century, Finnish immigrants in North America were involved in a variety of cultural activities. Among the many interests the immigrants had were music and songs, which were a natural part of their existence. My intention here is to give a brief overview of this area of tradition which is less known in every way. I will provide an idea of the Finnish-American identity described in the songs of Finns in America between the years 1900 and 1930. Sometimes only written by hand, published in a small booklet or printed by a Finnish-American organization as a songbook, or sung on majorlabel records, in these songs there can still be found traces of the individual mind and group voice of these immigrants. The identity itself has a double meaning and is very well suited as a focus when discussing these songs. As we all know, one meaning of identity is sameness and another is distinctiveness, where the latter seems to refer to individual identity and the former has to do with a sense of commonality between several persons who constitute a group.' The song texts in question often more or less follow these given identity patterns. I am simply trying to find an answer to the following question: What was the identity that an individual Finn or Finns as a group wanted to manifest to other ethnic groups during the "golden years" of Finnish-American culture in the United States. Naturally, one can't avoid the effect of acculturation which I will discuss briefly while commenting on certain Finnish-American songs.

Keywords: Finnishness, identity, folksongs, emigration, integration

\section{Why song?}

First, we may ask: "Why do songs have words?". And why are these so important? Hugh Mooney has mentioned ${ }^{2}$ that songs can show changes that have taken place in the values and lives of immigrants. As an example he used the United States, pointing out that between 1895 
and 1925 songs expressed a patriotic attitude, favoring working and the enjoyment of life. From the 1920s until the 1940 s, songs reflected more negative attitudes, describing disappointments and moments of despair, especially during the Great Depression. Simon Frith ${ }^{3}$ has similarly said that songwriters want to follow closely those groups or those people who live by the general norms of society.

Besides these values, songs can reveal the general beliefs of people. From this point of view DiMaggio, Peterson and Esco have looked at country music in the United States, especially after 1950s. They claim that these song texts are about the romantic love, the gap between the sexes, and hard work in the cities. The words bring out opposites, for example when the old values of life in the countryside are used to measure city life. The songs reflect new expectations, symbolic forms, and the attitudes of the listeners. ${ }^{4}$

Naturally, Finnish-American music and especially song texts can be looked at from such a perspective; but what is more interesting is that these songs describe the acculturation and identity of the Finns in the North American continent. We know that when different cultures meet, people must make adjustments in their own culture. As John Berry has said, there are many stages in this process. Everybody within the ethnic cultural group must decide how important it is to an individual to preserve his or her own culture and cultural identity. ${ }^{5}$ How did this happen with the Finns in North America? What can we read from the songs of a different epoch? Where is the Finnishness in these songs?

First, we have to keep in mind that Finnish people, like many other immigrants who arrived in the United States and Canada, were used to singing. For Finns, the active and lively use of folksongs was not only for amusement and enjoyment but part of their communications in Finland in the 1900s. Even these broadside and folksongs were regarded by the nationalromanticist elite groups as no-good lower class expressions, which could not be compared in any way with the great songs of Kalevala, compiled by Elias Lönnrot. Still, these lowerclass songs became quickly known in nearly every part of Finland ${ }^{6}$.

And the times they were achanging. Industrialism which was becoming more and more important in society also had its effect on life in general, even in the small villages. Young people got new idols. These new idols were transformed to vernacular songs that told of changing attitudes. Youth rebelled against their parents and wanted their freedom here and now.

Voi kuinka komialla paikalla

On oman kullan koti

Valtamaantien varrella

Ja klasin all' on joki ?

\footnotetext{
${ }^{3}$ ibid.

${ }^{4}$ ibid.

${ }^{5}$ Berry (1990)

${ }^{6}$ Asplund-Hako (eds.)(1981): Kansanmusiikki

${ }^{7}$ Virrankoski(1994), manuscript text. Niemelä Homearchives.
} 
It is a handsome place

The home of my beloved one

Beside the highway

And underneath the window a river flows

This unknown songwriter is expressing his real or imagined freedom by boasting that his beloved is living in a mansion, which means that he is somebody who can live as he likes and can cross social class barriers by having a sweetheart from a class higher up than his. The possibilities that came with working in logging, railroad or channel-building camps helped in this process of individual independence. So did the migration to America.

\section{Minä menen Ameriikkaan,}

Sinne menee kaikki.

Sokerisannalla sannoitettu

On Amerikan raitti ${ }^{8}$.

I am going to America

Everyone is going there.

The finest sugarsand covers

The road in America.

These local songwriters and musicians used the large repertoire of existing songs, they knew well all the subjects and the style patterns and improvised whenever it was needed, based on the demands of the listeners and the dancers. The song above is an example of this. The text contains those common and shared ideas of the Golden Land of Freedom, unconscious.

These songmakers and performers were highly respected in their homevillages. Often they were artisans, shoemakers and tailors who travelled and were thus able to see and hear matters more videly than the ordinary villager. Usually, the ability to sing and play was not of special import.

\section{To America}

From the passport and passenger records it can be seen that between 1870 and 1930 about 400,000 persons left Finland as immigrants to North America. This was roughly $10 \%$ of the total population of that time. It is estimated that only 75,000 of the immigrants returned.

In Finland, the immigration factors to foreign countries, especially to America, were much the same as in Europe. The pushing factors were the rapid increase of population and as a result of this, the rapid growth of landless people. The pulling factors were the need for manual labor and the idea of nearly unlimited possibilities for success. In Finland's case there were also other reasons for migration. One of them was the russification activities of the Tzarist government in the 1890 s and 1900 s. Another was the inheritance rule, which 
meant that only the oldest child, usually male, could inherit land. The other siblings of large families had to seek their fortune elsewhere. It was no wonder that many Finns left, with the goal in mind that they could get "richer" fast in America, and then return to the old country to buy that so much coveted farmhouse and land. The majority of Finns came from rural areas. For example, in 1893-1910 over 200,000 immigrants (about $70 \%$ ) were the landless, cottagers, crofters, farmers or their children. The artisans and workers made up $16 \%$. The remaining $14 \%$ included shopkeepers, businessmen and scholars. ${ }^{9}$

Among those young Finnish men and women who immigrated to the United States and Canada were many individuals who kept up their singing and music playing as an integral part of their life even in totally new surroundings. Granted, it may have been simply humming or singing while doing the chores or working in the forest, but it was there.

Already when the little vessel or steamship had barely left the harbor of Hanko in Finland, the passengers were singing. They sang hymns, folksongs or patriotic songs. And this was the accepted way of telling about one's feelings through a shared experience.

\section{Meillä ei kotia täällä \\ Olemme joukko vieraita vaan \\ Vie kohtalo meitä \\ outoja teitä \\ Vaan kotiin ei milloinkaan ${ }^{10}$}

Here we have no home

We are only strangers

Our destiny carries us

towards unknown roads

but never homeward

As early as 1890 s one could hear this kind of sad song, which reflected the feelings on the minds of the newly-arrived Finns in America. Back home they had sung folksongs about the wanderers and orphan boys and girls, but this was totally new; now they were all experiencing the same thing - being strangers somewhere in a world that they could not totally understand. Many individual Finnish-American performers sang these "homespun" songs not only for themselves but for the whole community, as a sign of a certain Finnish identity.

In the United States many kinds of folksongs were taken to active use again as the singing tradition became mobile. It was no wonder that young Finns, men and women, were again singing typical traditional songs about nature, wanderers and most of all, lovesongs, like they had done while still at home:

Äiti, äiti älä soimaa

Että häntä lemmin näin

Eihän ole mulla voimaa

Irti päästä lemmestäin ${ }^{\prime \prime}$

\footnotetext{
${ }^{9}$ Korkiasaari (1989)

${ }^{10}$ Turpeinen : "Meillä ei kotia täällä“, Columbia Records.

"Kansanlauluja, no publishing year, printed in USA.
} 
Mother, mother, do not chide me

Because I love her so

I don't have the strength

To be set free from my love

Good examples of this continuing tradition can still be found in the Finnish songs collected by Marjorie Edgars (in 1937) and John Lomax (in 1938) from Michigan and Minnesota. The following one tells of the sadness of departure when two lovers are separated by their destiny. This happened to many Finns who immigrated to the United States.

Sinä pidit musta ja minä pidin susta

Ja eron piti tulla meistä.

Ja mitä mun silmäni kesken kuivi

Surun kyynelistä.

You liked me and I liked you

But still we had to part.

And why my eyes are dried in between

Those tears of sadness ${ }^{12}$

Some of the songwriters did look around at what was going on in their society. They took the point of view of the Finn and gave their criticism accordingly. They used old melodies but adjusted the lyrics to correspond to their reality in the United States. The following example is about working in the mines:

Niin musta on, musta on ikuinen yö

Ja kello lyö kaksitoista

Torkkuen toverit istuskelee

Hikikarpalot kulmillahan

So dark, so dark is the everlasting night

And the clock strikes twelve times

The comrades sit dozing off

Beads of sweat on their brow ${ }^{13}$

The mine was described as Hell, where the shifts created the rhythm, and the men worked on, their faces covered with soot and sweat pouring down their bodies. But the men had pride in their work, they were tough Finns who could do the job. Their self-esteem was high. Just like in the old country.

One of the first great performers of Finnish songs in the United States was opera singer, choir conductor and violin player Juho Koskelo. He was among those first-generation Finns who recorded for the major labels, Columbia and Victor, between 1910 and 1920. From the beginning his recordings were a success and the Finns went gladly to see him perform on the

\footnotetext{
${ }^{12}$ Separated songtext. Niemelä Homearchives.

${ }^{13}$ Uusi Työväen Laulukirja (1912): Kaivosmiehen laulu, Työmies Kustannusosakeyhtiö, Hancock, Michigan.
} 
hall stages. Juho Koskelo was also an active member of New York's Finnish Socialist Federation. He sang a lot of Finnish folksongs, a few workers' songs and some hymns. These were popular among his fellow men and women. Especially in his folksong performances he tried to achieve the traditional way of singing and be like one of the rural men. One of his songs was "Köyhä poika"("The poor lad"):

Ei saa moittia köyhää poikaa

Mies se on arvoltansa

Kyllä se laittaa jahka se joutuu

Kartanon kullallensa ${ }^{14}$

Do not blame the poor lad

He is still a man

He will build when he can

A manor for his sweetheart

Another similar performer was Jean Theslöf. Like Koskelo, he sang folksongs. Perhaps his best known folksong among the Finnish-Americans was "Isoo-Antti ja Rannanjärvi" ("BigAntti and Rannanjärvi"). One could fairly sense the rebellion in the air when the song echoed out, and recall how in Härmä, in the Old Country, the knife men had looked for fame and glory in the same manner as Jesse and Frank James in the United States:

Isontalon Antti ja Rannanjärvi

Ne jutteli kahden kesken:

Tapa sinä Kauhavan ruma vallesmanni

Niin minä nain se komian lesken ${ }^{15}$

Antti from the Big House and Rannanjärvi

talked to each other saying:

"You shall kill the ugly sheriff of Kauhava

and I will marry his handsome widow"

It was not surprising that this was a well-liked song. For many, it gave the feeling that they were still someone. It took them back to their Finnish identity.

He also performed Johan Alfred Tanner's couplets for the Finnish-Americans. Tanner was a man who assumed many characters in his song performances, he even gained a reputation for doing "bond comic"/ farmhand pieces. These simple farmhand acts and songs were enormously successful in Finland in 1910s and in no time, the songs reached Finnish communities in North America. Tanner's acting and singing can be compared with the Swedish comedian Hjalmar Peterson, better known as Olle i Skratthultt, who was very popular among Swedes and Finnish Swedes wherever he performed in the United States.

Theater was one of the active forces which was as well keeping up Finnish song culture. Many

\footnotetext{
${ }^{14}$ Koskelo (1915): Köyhä poika, Columbia Records

${ }^{15}$ Theslöf(1925): Isoo-Antti ja Rannanjärvi, Columbia Records.
} 
Theater was one of the active forces which was as well keeping up Finnish song culture. Many performances incorporated a lot of music. Some were folksongs. Of course this was the case if the theater was accepted.

Not only the solo voices reached out from the crowd. Finnish choir singing landed quite soon after it had assumed its place in Finland. The first male and mixed choirs were formed by Pekka Vesterinen already in 1889 in Calumet, Michigan.

\section{The jazz age}

What was going on at the same time in American music culture? Ragtime, and after it, jazz came to the stages. Ragtime was more than music...it was a lifestyle. The phenomenon of Dance Mania which lasted from 1911 until 1917 in the United States affected people's lives a lot. Dancing was up-to-date. Dancing became an alternative world to the cozy hearth of home. At the taxi-dance halls young girls from broken homes were hired by immigrants anxious to be Americanized, by cripples in search of love, by high society slummers. The attraction of ragtime dance with the ragtime band in the ragtime dance hall was that it promised immediate satisfaction, by instant contact.

There are a few examples that even Finnish immigrants observed and paid attention to these new ways of life which differed so much from their old habits. As the American environment offered more attractive entertainments, children of Finnish immigrants partly resisted their parents' attempts to drag them along to the Finn Halls and Finnish Churches. By some opinions young Finnish Americans were in danger of drifting into the dangers of immorality. Some of the older Finnish Americans thought that the actions of the younger, Americanborn generation were becoming disturbing. Instead of participating in Finnish-American activities, young people were drinking and frequenting dance halls, while girls were painting their lips and nails bright red ${ }^{16}$.

And then there was jazz. White kids in short pants watched King Oliver and his band and shivered to the shouts of Louis Armstrong's trumpet. Many became hooked on jazz - and they came from all classes. There was Bix Beiderbecke, middle-class and Lake Forest Academy-educated. There was Hoagy Carmichael from Indiana University. There were Jewish slum kids like Mezz Mezzrow who longed to be black. And there were others like Benny Goodman, Glenn Miller, Jimmy and Tommy Dorsey ${ }^{17}$. Many of the musicians in the bands that were forming were immigrants. Among them were a few Finnish-Americans such as Lee Coleman and Sylvester "Hooley" Ahola, a trumpet player who played with top names in some 4000 recordings. The well-known Finnish-American singer Hiski Salomaa made his own comment about the jazz age in the song "Jaassii“":

\footnotetext{
${ }^{16}$ Whitcomb (1972): After the Ball.

${ }^{17}$ Whitcomb (1972): ibid.
} 
Nyt jaassien tahti ja tanssin mahti

Tätä maailmata hallitsee.

Se ukkoja, akkoja, rampoja, nuoria

Tanssihin villitsee.

Se polvia vääntää ja ahtereita kääntää

Ja tunteita hemaisee ${ }^{18}$

Now the rhythm of jazz and the power of dance

Are ruling this world.

It's bewitching men, women, the crippled and the young

To dance

It swings the knees and the behinds

And stokes up the feelings

\section{The Finn Hall singers}

Naturally, it is difficult to categorize the different musical genres in the ethnic market in the $1920 \mathrm{~s}$, and much of what was cut on record was as rich and complex as the traditional culture that inspired it. Among the many genres, one of the most popular consisted of music with traditional roots that was newly composed in America. Most ethnic pieces, whatever their background, probably did not appear on record in strictly traditional form. Some were entirely new compositions in traditional style; others were older pieces arranged for new instrumentations. Finnish Americans were no exception. But Finnish-American performers had many more venues than just records to bring out their talents. Besides family celebrations, there were several Finn Halls that were built up in Finnish communities, and the Finntowns in American and Canadian cities were glad to have them.

These new performing talents didn 't come from nowhere. Some of them had had a very good schooling in Finnish-American brass bands, under fine bandleaders. Among these musicians were for example Antti Syrjäniemi, William Syrjälä and Sylvester Ahola. Some of them had been trained at home with music lessons given by a music teacher. Among these were Sylvia Polso, Paula Salin, Lyyli and Aili Vainikainen, Leo Hill, Hannes Laine, Henry Koski, Oliver (Olavi) Silfvast, Walter Toppila and Viola Turpeinen, to mention a few.

It must be noted that the handful who distinguished themselves with the most success were outstanding not only because of their exceptional talents as performers but also because of their originality and creativity. They used the "homespun" as a basis but many also composed their own material or at least a good part of it. They were also represented in the content of their material. In several cases there was a strong "message" of a certain "Finnishness" - of maintaining the identity. Of these, not just one single performer dominated the Finnish-American halls but actually there were three who stood out from the numerous performers in the 1920 s and in the beginning of the 1930s. They were Leo Kauppi(nen), Arthur Arkadius

\footnotetext{
${ }^{18}$ Hummasti (1990): Children and social change: Thoughts on the Second Generation of Finnish Americans.
} 
Kylander and Hiski Salomaa. Granted, Viola Turpeinen was far more popular than any of these male performers, but she was mostly an instrumentalist, not an ethnic troubadour, even though she sang a few folksongs too. But Kauppi, Kylander and Salomaa were singers who were bridgemakers between the old tradition of Finnish songs and the rise of the FinnishAmerican song tradition.

\section{Leo Kauppi}

Leo Kauppi was born in Kotka, Finland on February 4, 1900. In the early years he was not very interested in singing. Closer to his heart were sports and especially wrestling. But as time passed he picked up singing and started performing in the smaller festivals near Kotka. As a young man he worked in many kinds of jobs. At one time he was a sailor, leaving his ship in Canada in 1920s. He continued wrestling as a hobby and won the Finnish championship in wrestling in 1923. Soon after this he decided to go to America. He found a new home in the Bronx in New York, where he lived from 1924 to 1931. In New York he had more possibilities for singing and there he also started his active couplet singing career. His regular venue was the "Työn Temppeli" hall on 126th Street, and he also sang in the other workers' halls.

Between the years 1926 and 1931 he made 40 recordings for Columbia Records in New York. Among them were "Maailman Matti" (later known as "Mailman Matti"), "Kuuliaiset Kottilassa", and "Herra Petteri" which sold thousands. His most famous song was the waltz melody "Meren Aallot" ('Wawes of the Sea'), lyrics written by himself, the melody composed by another Finnish-American accordionist Antti (Andrew) Kosola.This alone sold about 30,000 copies. I can say that Leo Kauppi's songs demonstrated Finnish identity in the way of folksongs. I will give you an example "Maailman Matti" - "Matthew in the Big World":

\section{Matti minä olen tästä maailmasta \\ Vaikka varreltani matala \\ Vaikka elämäni itkuksi muuttaisi \\ Tuo kohtalo katala \\ Vaan en luotu ole itkemään \\ Vaikka ohdakkeita kitkemään \\ Hurra hurraa hoi \\ Minun lauluni soi \\ Noilla maailman markkinoill'. ${ }^{19}$}

I am Matthew of the world

Though I am not so tall.

Even if faithless fate

Turns my life to weeping.

I was not born to cry

Even if I have to cut down the thistles

Hurray, hurray hey

My song is singing

Wherever in the world I go.

\footnotetext{
${ }^{19}$ Kauppi (1926): Maailman Matti, Columbia Records.
} 
Here one can again see a typical Finnish wanderer folksong. It is about the man who boasts of his freedom to go as he likes, even if the whole world were against it.

Besides ballads and folksongs, Leo Kauppi also sang a lot of Tanner's and Pekkarinen's couplets, where the actors and surroundings were from the Old Country. To my mind, we can safely assume that since the singer was able to choose his songs, at least some or most of these couplets must have been very popular among Finnish-American audiences and the record-buying public. This tells something about the identity.

When the Finnish-American workers went to rebuild Russian Carelia in the 1920s and 1930s, Leo and his wife Hilda Kauppi were among them. They got a new home in Petroskoi. First Leo worked as a wrestling instructor and swelter. But besides these jobs, he continued singing on the radio. Later he shared the same destiny with many other Finnish Americans in Russian Carelia. During Stalin's Terror in 1937 he was arrested and convicted for ten years to a prison camp. He never came back.

\section{Arthur Kylander}

Arthur Kylander was perhaps the best known of those three men, if we think of all the Finnish-American communities that these performers toured. Arriving in America in 1915 at the age of twenty-two, Kylander became well acquintated with the lives of the working class audience. He moved around widely, seeking the typical Finnish immigrant employment of lumberjack, woodworker, or miner wherever he could find it, in Maine, New York, Pennsylvania, Ohio, Minnesota, and finally California. He began publishing sheet music in 1920 and composing his own comic songs in California in 1926, when he decided to try to become a professional entertainer. 1927, the next year, he left the West Coast for his first tour of the Finnish communities, which was even more successful than he might have expected: while traveling through Montana and Minnesota, he met and married his wife, a pianist who served superbly as his accompanist. He established such a good reputation that the Victor company agreed to record his first songs, twenty of them, between 1927 and 1929.

There are a few tunes that are closely associated with Kylander and his experiences. One is "Siirtolaisen Ensi Vastuksia" (The immigrant's first difficulties) which dwells on the language difficulties of a newly arrived immigrant worker, whose first English phrase is "No, Sir" and "Lumber Jäkki" which tells about the hard life of the lumberjacks in the backwoods:

\footnotetext{
"Greetings from the wild,

From the wilderness,

From the backwoods

From the pastures of wild nature,

from the bosom of the forest

Where the delights of the city

Are lacking and the fellows live

Like monks in a monastery

Thus patience overflowed
}

The Lumber Jack left the camp and concluded: 
"We have only one life to live,

Fellows, let's go and celebrate in the city"

The Finnish-American lumberjack is on the loose. Too much forest and just too many men is too much for him. But besides this, there is left some of Finnishness in Kylander's song because the next verse says:

Sentimentally the bosses sing,

About the backwood working men,

And how poetic it is to live

Beneath the forest pines.

Lumberjack, certainly,

Is fortune's son, isn't he.

'Cause he can live out all his days

beneath the tall pine trees.

As for food, it always seems,

He gets the fresh meat,

Preserved in Chicago

For the last ten years or so.

They say the berries on his plate

Are those sweet strawberries,

But in the city they call them

Those awful "navy beans". ${ }^{20}$

The second verse shows the social gap between the common folk and the masters. This was a generally known situation, deeply rooted in the Finnish mind as well as in the folksongs. In this case, I don't believe that it arose merely from the reality of life in America, rather I see it as a reflection of tradition which was repeated.

\section{Hiski Salomaa}

Hiski Salomaa was a well-known character on the stages of the halls. Although he had an interest in the workers' cause, he was also well accepted by other Finnish-American groups. He had arrived in America in 1909. After World War I, he worked as a tailor in Massachusetts and Michigan. Making ballads and songs had always been his hobby. First he performed at small festivities and family celebrations, but soon he was asked to the stages of the halls. Most of his melodies were derived from folksongs, but the texts were mostly his own. Some of the pieces were semi-autobiographical, such as "Savonpojan Amerikkaan Tulo ("The Arrival of the Boy from Savo to America") and "Taattoni Maja" ("My Father's Cabin"). The latter's lyrics follow the traditional song. The following three verses are a good example:

\footnotetext{
${ }^{20}$ Kylander (1927): Lumper Jäkki, Victor Record Company.
} 
Ku kartanon koiran koppi

Vaan oli se mulle niin hellä ja nätti

Ja ainoa rauhan soppi. ${ }^{2 l}$

The home of this boy was no bigger

Than the kennel on the estate

But for me it was so tender and pretty

And the only place of peace

Taattoni maja oli matala ja pieni

Ja porrasta siin oli kaksi

Kun läksin taattoni porraspuulta

Tään maailman kulkijaksi

My father's cabin was low and small

It had just two steps

When I left my fathers threshold

To be a wanderer of this world

Taattoni majan raitilla kasvoi

Kaksi pihlajapuuta

Niiden juurilla istuin illat pitkät

Ja katselin kaunista kuuta.

Besides my father's pathway grew

Two rowans

On their roots I sat those long nights

Looking at the beautiful moon

These traditional songs make up a good quarter of his songs. Then there are the songs that deal with the American way of life and the Finnish-Americans in it.

One of these was his best-known song, "Lännen Lokari" (the Logger of the West") which is the boasting story of a Finnish lumberjack who travels widely for work, even to Alaska, taking pleasure in his freedom. He is absolutely a cousin of Kylander's lumberjack. But Hiski Salomaa too had sharp eyes for the issues within the Finnish-American society and the daily aspects of life in general. In North America on the whole, Finns were assimilating well to American society. One example may be found in Hiski Salomaa's song "Dahlmannin paartit" ("The Party at the Dahlmanns"):

The party guests surprised Dahlmann, the children slept in the corners The dog was barking at the guests and Mr Dahlmann himself was serving the drinks He gave a little drop for the dog, and Bobby got into a better mood

The table was beautifully laid and the wines were already served in the glasses

\footnotetext{
${ }^{21}$ Salomaa (1932): Taattoni maja, Columbia Records.
} 
The gramophone was playing a waltz and the younger people wanted to dance too. I was asking Miss Hill to dance with me, the others were drinking and eating Norwegian Herring.

And the early morning was great because even I started to swing.

Miss Dahlmann was woken up and that tablelamp was bought for her as a gift. We ate hot dogs, ice creams and with the beer we moistened our lips. ${ }^{22}$

As we can see, assimilation had surely taken its course. The Finns had little by little changed their eating habits, and got used to the American food culture. The only exception was the Christmas table.

But also the problems of the Finnish-American society were coming out into the daylight. Hiski Salomaa talked about them in his songs "Emännät piknikissä" ("The Ladies at the Picnic"), and "Kemppaisen avioelämää" ("The Married Life of Kemppainen"). From the latter:

It was the greatest mistake, said Kemppainen only now

when I married that Tildu Miettinen as my wife

She goes to dances, she stays not home, and I take

care of the children

the love between us has turned ice-cold.

Before I was going daily to work and I was among

the best men

but while the "thieves" started to visit Tildu

and that finally broke down our home when Tildu

sold yesterday all our things at half price. ${ }^{23}$

The workers' organization IWW (Industrial Workers of the World) commissioned two songs from him. They were "Vapauden Kaiho" ("The Longing for Freedom") and "Elisan Valssi" ("Elisa's Waltz"). These were among the few songs that directly showed Hiski Salomaa's working class commitment.

Meill' vapauden kaiho soi, ain rinnassamme toverit oi Siks' yhteistyöhön rintamahan käy, pelastusta köyhille ei ennen näy. ${ }^{24}$

The longing for freedom is echoing Forever in our chests, oh comrades. So co-operate, join the common front Until then, there'll be no salvation for the poor.

Now the wanderer's idea of freedom to do as he pleased had changed to the need for freedom to all workers of the world. "My" need was replaced by "our" need. Naturally, this call reached

\footnotetext{
${ }^{22}$ Salomaa (1929): Dahlmanin paartit, Columbia Records

${ }^{23}$ Salomaa (1930): Kemppaisen avioelämää, Columbia Records

${ }^{24}$ Salomaa: Vapauden kaiho, Love Records RLPL - 17
} 
a minority of Finnish-Americans, but that minority had especially active members and their voices were heard and they were visible. There are some lively texts describing how Finns got into the American working life. Finnish men generally found jobs in various mining towns, forest camps and farms. The women worked as domestics as so many other immigrant women at that time and later. There are several songs about the jobs of the Finnish men in America. In those times, political movements were clearly reflected in the songs and many of them state more or less clearly the opinions of the workers. Several songbooks with idealistic workersongs were also published but they also included a few folksongs.

Besides his work as a tailor Hiski Salomaa also later owned a bar in New York, where he had moved with his wife at the end of 1930s. In the Big City, he enjoyed the company of the Finnish-American carpenters and railway men. For them he was still singing his songs in the 1940's, even as his active days of performing were over. He died in New York in 1957.

Among the Finns in America, folksongs were still popular in the 1920 s as they had been in the 1910 s. They were performed in the Finn Halls as a part of the musical program. They were also sung in the plays that had music in them. So it was not surprising to hear the next traditional song:

\section{Among the pine trees I have my cabin}

In the beautiful wilderness of Finland

Among the pine trees there is a lake

Which shimmers in the morning sun ${ }^{25}$

The message of this song was a bit different for those Finns who had settled in the country and those who were born in the country. For the former, it represented the idealistic and nostalgic times of by gone days in the old country, Finland; for the latter it was only a part of their cultural heritage. For them, the same meaning was not there or the same identity, as there was for the immigrants.

The young Finns had a habit of having dances at home or in vacant houses. Out of the eyes of the others, because quite often the villages and cities had a good number of church-going Finns, and the young people did not want to offend them, as the church-going people considered the dances sinful.

There were new humoristic songs too. The position of women underwent great changes in the 1920s. They received the right to vote in the United States. Also, many everyday habits changed. The women started to curl their hair, wore shorter dresses than before and began to smoke, to use lipstick and drink alcohol. They even talked about issues that were earlier reserved only for men, such as politics and sex. The latter subject deeply shocked the moralists of the time. The Finnish-American songmaker Antti Syrjäniemi expressed the modern times in his song "Oh women":

\footnotetext{
${ }^{25}$ Information given to writer in 1993 by Prof. James Leary in Madison, Wisconsin, U.S.A.
} 
How you do walk

It must be easier

Going down that narrow road

When you remember to shed

Your extra clothes into the basket

It is enough, what you naturally wear

In summer and in winter

If only, into the glowing embers of your spirit

Like a hog burrowing into the straw

I could forever lay my head ${ }^{26}$

\section{The great depression}

The 1920s ended in the United States of coming of the Great Depression, which had a larger and deeper impact than Americans could at first understand. Yet in 1930, people were generally optimistic, but soon the problems could be seen in towns and in the countryside. On the outskirts of towns there began to appear the shacks of vagabonds and homeless people, called "hoovervilles". The income of the average person had collapsed to only one third of that of 1929 and unemployment increased rapidly. In 1930 there were four million people without work in America, next year there were eight million, and when Roosevelt was elected as President in 1932, the figure was as high as 13 million and still rising.

Being without work was not new for the Finnish-Americans, but the Great Depression got a deeper and longer hold on them than before. When the mines, mills and factories were forced to shut down, then it happened as Arthur Kylander has described it in his song "Työttömän valssi" ("Come Around Again"), the people really felt that they had been pushed away from everything and that they had to go a long way to find something to do, to keep them alive.

Kun kuljin ma kulkurin lailla,

oli mullekin käynyt niin,

ett' työtä olin myös vailla

menin tehtaisiin ja kaivoksiin.

Vaan kaikkiall' silloin sain kuulla vain sen

Come around again, yes, come around again

Me ehkä jos joskus viel' tarvitaan.

Ei tiedä vaan, come around again. ${ }^{27}$

When I was wandering like a hobo,

It had happened also to me,

That I had no job

$I$ went to the factories and mines.

But everywhere I had to hear only this:

Come around again, yes, come around again

${ }^{26}$ Antti Syrjäniemi's handwritten songbook. Copy of it is at Niemelä Homearchives.

${ }^{27}$ Tamminen (1927): Työttömän valssi, Victor Records. 
We might need you one day.

But one can't say, come around again

The same view of the time is shared by the bluesman J.D. Short:

I went to the factory

where I worked three years or more

and the boss man told me

"Man, I ain't hiring no more" 28

Hiski Salomaa describes this in his song "Värssyjä sieltä ja täl̈lä" ("Verses from Here and There"):

Many musicians have sold their whistles

and as lunch have eaten their last moneys

Many boys have already laid down their mittens

and drank the poor whiskey of today

so that the feet have kicked the bucket

so that we have sung for the last time 29

But in fact, even though times were hard, many Finnish-American singers and musicians were able to find possibilities of performing among the Finns. Those who had already established a good reputation and were naturally in a better position; although the record companies did not publish new material in the same numbers as before, they were able to continue touring.

One of them was Viola Turpeinen and her group. She was always long-awaited even in the smallest towns of the Finnish regions. She was also an important figure in that she was one of the Finnish Americans who played those Old Country waltzes, polkas and schottises, which were treasured as the heart of Finnishness by the audience. Also, it did not hurt that she was very well known among Americans as well, the same way as the accordionist Frankie Yankovic or Pietro Deiro.

Antti Syrjäniemi found a fine way of telling about Viola Turpeinen in his song "Viola Turpeisen tanssit Kiipillä"("Viola Turpeinen Dances at Cape Ann"), which begins:

I still can remember lively

When that Turpeinen girl was in the group

It was so easy going on

I just wonder how all could survive

When the accordion was "singing"

On the bosom of the girl

As well the young and

The old were dancing eagerly ${ }^{30}$

\footnotetext{
${ }^{28}$ Titon (1994).

${ }^{29}$ Salomaa (1931): Värssyjä sieltä ja täältä, Columbia Records.

${ }^{30}$ Syrjäniemi (1929): Viola Turpeisen tanssit Kiipillä, Victor Records.
} 
One symbol of optimism was a song by Viola Turpeinen called "Unelma Valssi" ("The Dream Waltz"), which became very popular among Finns in the 1930s and remained long one of the most requested songs.

When the gentle melody, so sweet, is opening the dreams

Then the lad offers his hand to the maiden

Oh slowly, only with their glances

They will reach the dream

It is so good to be a boy and to have the heart of a girl. ${ }^{3 I}$

Naturally, the hard reality did not only consist of day-dreaming. Many of the unemployed Finns who had arrived from the countryside could return to their homefarms and give a helping hand. The Great Depression was finally overcome when World War II began and the United States joined it.

\section{Epiloque}

I have based this overview on the preliminary results of my Licenciate thesis. I have looked at and classified about 1,500 Finnish-American song texts and 800 Finnish-American recordings from the years 1900 - 1930. As far as I can see, it seems that until World War I, Finns and Finnish Americans were mostly enjoying their own "old country" song and music tradition, which stemmed from different places. Four active forces keeping up this living culture, behind the amateur and professional singers, were Finnish churches (those that allowed singing), the Temperance Societies, the Workers' Socialist Federations and the Finnish Theaters. They all gave opportunities to the individuals and groups to continue the singing tradition.

The image of Finnish identity and Finnish Americans remained the same for a long time. For example the figure of the wanderer is one of the main characters in Finnish folksongs. I do not mean that this always reflects reality, but it is the image that has been given out, like saying "this is me - this is us". It is easy to identify with. Between 1900 and 1920, there were only a few songs that said anything about assimilation. Half of the songs are about Finnish nature, one third about love, with different variations, one third about work, and one third about patriotic feelings (the groups are partially overlapped). These old country songs might have been a kind of buffer between the Finns and the rest of society, so that they were able to maintain their identity in the new and strange surroundings. We have to remember that Finns were only one small group among many nationalities who arrived in America. This maintaining of a certain identity, real or imagined, lasted for quite a long time. If interpreted through the ideas of assimilation, it shows that the first immigrant generation of Finns kept themselves more as an inside group, somewhat segregated.

${ }^{31}$ Turpeinen (1928): Unelma Valssi, Victor Records. 
After 1920s the picture started to change. About one fourth of the themes of the songs describe Finnish-American life in one way or another. There naturally remained old Finnish folksongs, but their number dropped to one fourth theme-wise. The worker songs represented one fourth, popular songs, all kinds of them, such as Viola Turpeinen's "Dream Waltz", made up two thirds of song themes.

The songs began to integrate more elements from Finnish-American lives, showing more connection with the main culture. More than before, the songs told us about who we thought we were. Now, side by side there were the "old country me" and the "new country me". The Finnish Americans little by little gave credit to themselves for being who they were. But as nothing happens overnight, these were just the first steps. As an example of the identity issue, I have mentioned such songs as Kylander's "Lumber-Jack" and Salomaa's "The Party at the Dahlmanns". Finnish Americans had found the balance between old and new. They were moving towards integration.

\section{References}

Ala-Könni, Erkki. (ed.). 1978. Härmän laulukirja. Tampereen yliopiston Kansanperinteen laitoksen julkaisu 5. Vammala 1978.

Asplund, Anneli and Matti Hako (eds.).1981. Kansanmusiikki. Helsinki: SKS.

Berry, John W. (1990): Psychology of Acculturation. In: J.J. Bermans (eds.). Cross-Cultural Perspectives. Nebraska Symposium on Motivation 1989, 7. University of Nebraska, Lincoln, 1990.

Frith, Simon.1987. Why do songs have words? Social Review 1987 Monograph 34.

Hummasti, Peter G. 1990. Children and social change: Thoughts on the Second Generation of Finnish Americans. In: Finnish Identity in America, edited by Auvo Kostiainen Turku: Institute of History, General History. University of Turku, Publication Nr 11.

Jacobson-Widding, Anita.1983. Identity: personal and socio-cultural, Uppsala 1983.

Korkiasaari, Jouni. 1989. Suomalaiset Maailmalla. Turku: SiirtolaisuusinstituuttiMigrationsinstitutet.

Syrjäniemi: Antti Syrjäniemi's handwritten songbook. Copy of it at Niemelä Homearchives.

Titon, Jeff Todd. 1994. Early downhome blues : a musical and cultural analysis, Chapel Hill

(N.C.): University of North Carolina Press.

Uusi Työväen Laulukirja.1912. Kaivosmiehen laulu. Hancock, Michigan: Työmies Kustannusosakeyhtiö.

Whitcomb, Ian. 1972. After the Ball - Pop Music from Rag to Rock. Baltimore (MD): Penguin Books Inc.

Virrankoski, Pentti. 1994. Manuscript text. Juha Niemelä Home archives.

Records:

Kansanlauluja, no publishing year, printed in USA.

Kauppi, Leo. 1926. Maailman Matti. Columbia Records.

Koskelo, Juho.1915. Köyhä poika. Columbia Records.

Kylander, Arthur. 1927. Lumper Jäkki. Victor Record Company.

Salomaa, Hiski. 1929. Dahlmanin paartit. Columbia Records.

Salomaa, Hiski.1930. Kemppaisen avioelämää. Columbia Records. 
Salomaa, Hiski. 1931. Värssyjä sieltä ja täältä. Columbia Records.

Salomaa, Hiski. 1932. Taattoni maja. Columbia Records.

Salomaa, Hiski. Vapauden kaiho, Lännen Lokarin Kootut Teokset, Love Records RLPL 17. Syrjäniemi, Antti. 1929. Viola Turpeisen tanssit Kiipillä. Victor Records.

Tamminen, Kosti. 1927. Työttömän valssi. Victor Records.

Theslöf, Jean.1925. Isoo-Antti ja Rannanjärvi. Columbia Records.

Turpeinen, Viola. 1947-1949. Meillä ei kotia täällä. Columbia Records. (Precise publishing year unknown).

Turpeinen, Viola. 1928. Unelma Valssi. Victor Records.

Interview: Professor James Leary in Madison, Wisconsin, USA,1993.

Separated songtext. Juha Niemelä Homearchives. 